\title{
Selectivity curves of the capture of mangrove crab (Ucides cordatus) on the northern coast of Brazil using bayesian inference
}

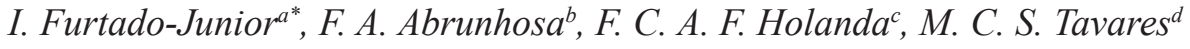 \\ anstituto Sócio Ambiental e Recursos Hídricos - ISARH, Universidade Federal Rural da Amazônia - UFRA, \\ Avenida Presidente Tancredo Neves, 2501, Montese, CEP 66077-830, Belém, PA, Brazil \\ bPrograma de Pós-graduação em Biologia Ambiental, Universidade Federal do Pará - UFPA, \\ Alameda Leandro Ribeiro, s/n, CEP 68600-000, Bragança, PA, Brazil \\ 'Instituto de Estudos Costeiros - IECOS, Universidade Federal do Pará - UFPA, \\ Alameda Leandro Ribeiro, s/n, CEP 68600-000, Bragança, PA, Brazil \\ dPrograma de Pós-graduação em Ciência Animal, Universidade Federal do Pará - UFPA, \\ Rua Augusto Corrêa, 01, Guamá, CEP 66075-110, Belém, PA, Brazil \\ *e-mail: juniorivan@hotmail.com
}

Received: September 29, 2014 - Accepted: January 29, 2015 - Distributed: May 31, 2016

(With 5 figures)

\begin{abstract}
Fishing selectivity of the mangrove crab Ucides cordatus in the north coast of Brazil can be defined as the fisherman's ability to capture and select individuals from a certain size or sex (or a combination of these factors) which suggests an empirical selectivity. Considering this hypothesis, we calculated the selectivity curves for males and females crabs using the logit function of the logistic model in the formulation. The Bayesian inference consisted of obtaining the posterior distribution by applying the Markov chain Monte Carlo (MCMC) method to software R using the OpenBUGS, BRugs, and R2WinBUGS libraries. The estimated results of width average carapace selection for males and females compared with previous studies reporting the average width of the carapace of sexual maturity allow us to confirm the hypothesis that most mature individuals do not suffer from fishing pressure; thus, ensuring their sustainability.
\end{abstract}

Keywords: fisheries exploitation, capture probability, sustainability, bayesian inference, coastal ecosystem.

\section{Curvas de seletividade da captura do caranguejo-uçá (Ucides cordatus) na costa norte do Brasil usando a inferência bayesiana}

\section{Resumo}

A seletividade na pesca do caranguejo-uçá, na costa norte do Brasil, pode ser definida como a habilidade do pescador em capturar e selecionar indivíduos a partir de certo tamanho ou determinado sexo (ou pela combinação destes fatores) o que sugere uma seletividade empírica. Considerando esta hipótese foram calculadas as curvas de seletividade para caranguejos machos e fêmeas utilizando-se a função logit na formulação do modelo logístico. A inferência Bayesiana consistiu em obter a distribuição posterior com aplicação do método Monte Carlo com Cadeias de Markov - MCMC no software R com o uso do OpenBUGS e auxílio das bibliotecas BRugs e R2WinBUGS. Os resultados estimados de largura da carapaça média de seleção para machos e fêmeas comparados com estudos anteriores que relatam a largura da carapaça média de primeira maturação sexual permitem confirmar a hipótese de que grande parte dos indivíduos maduros não sofre a pressão da pesca o que garante sua sustentabilidade.

Palavras-chaves: exploração pesqueira, probabilidade de captura, sustentabilidade, inferência bayesiana, ecossistema costeiro.

\section{Introduction}

Brazil's north coast has the largest area of almost uninterrupted mangrove ecosystem in the planet, occupying an area of $11,135.68 \mathrm{~km}^{2}$, with $1,823.00 \mathrm{~km}^{2}$ in Amapá, 3,894.00 $\mathrm{km}^{2}$ in Pará (Kjerfve and Lacerda, 1993), 5,414.31 km² in Maranhão (Souza-Filho, 2005) and $4.04 \mathrm{~km}^{2}$ in Piauí (Maia et al., 2006).
In these environments, the mangrove crab accounts for approximately $63 \%$ of the total biomass of mangrove epifauna, which represents $75 \%$ of the total fauna biomass (Koch and Wolff, 2002). In addition to its ecological function as a herbivore that consumes mangrove litter (Nordhaus et al., 2006), its capture is probably the most 
important economic activity throughout the entire coast of Brazil (Kjerfve and Lacerda, 1993).

The national production of mangrove crab was 6,818 ; 8,$184 ; 9,027 ; 8,535$ and 8,608 tons in 2007, 2008, 2009, 2010, and 2011, respectively (Brasil, 2011, 2013). The most recent detailed official statistics per state indicates a production of $59 ; 2,748 ; 1,198$ and 814 tons of mangrove crab in the states of Amapá, Pará, Maranhão, and Piauí, respectively. This represents $70.7 \%$ of the national production, which shows the importance of this resource in Brazil's north coast (IBAMA, 2007).

To ensure that a certain sample is representative of the mangrove crab population, fishing selectivity needs to be determined. If the fishing selectivity curve, i.e., the relationship between the relative retention frequency and the width of the carapace, is known, the error caused by the reduced perception of crab fishermen or animal escape can be avoided. Thus, the real frequency distribution of carapace width in a population can be determined.

Moreover, selectivity studies enable us to know the size above which the species becomes susceptible to a given fishery, as well as its mean and maximum capture size. In addition, the adoption of a minimum capture size is a measure taken in fisheries management to protect young individuals, maintain the reproductive stock, and control capture size.

When there is sufficient knowledge about fishing selectivity, managers are able to detect and possibly avoid growth and recruitment overfishing. Growth overfishing occurs when the individuals are caught during the rapid growth phase and recruitment overfishing occurs when the population is depleted to a level where it no longer has the reproductive capacity to replenish itself (Walters and Martell, 2004).

The Bayesian method has as advantage when compared with the classical method, the possibility of including uncertainty, i.e. a measure of the degree of plausibility of any proposition, independent of it being associated with phenomena measured by relative frequency (Berger, 1993). The gear selection model based on the logistic curve is believed versatile enough to describe the selection curve of any gear (Sparre and Venema, 1998).

Several studies have addressed the size of the first sexual maturation (Ivo et al., 1999; Vale, 2003; Silva et al., 2009; Linhares, 2010); however, fishing size selectivity has not been analyzed. The aim of this study was to use a Bayesian probabilistic model to estimate the selectivity curves during the catch of male and female mangrove crabs determine their size selectivity and test the hypothesis that the empirical selectivity of crab fishermen in Brazil's north coast protects the reproductive stock.

\section{Material and Methods}

The data used in this analysis were part of the databases of the Project ESTATPESCA of IBAMA and Fisheries Statistical Laboratory of the Federal Rural University of Amazonia LAPEP-UFRA, in addition, samplings performed by the authors were used. These data were randomly collected during the most and least rainy seasons, over a period of 10 years between 1998 and 2007, in the mangrove areas of Brazil's north coast (Pará, Maranhão and Piauí).

Samplings were performed with stochastic periodicity during low tide, with the help of (two to six) local fishermen, via the commonly used harvest method "braceamento" (arm work) as described by Maneschy (1993).

The data collected on the fishing trips were recorded in specific forms. The researchers accompanied 29 fishing trips in which 4,594 males and 1,420 females were captured. On arrival at the fishing site (mangrove), three squares of $25 \mathrm{~m}^{2}$ each and approximately $100 \mathrm{~m}$ apart were delimited. A total of 87 squares were sampled. Immediately after this delimitation the fishermen harvested the individuals of interest, without the interference of the researchers. When the fishermen left the delimited areas, the researchers collected all the remaining individuals.

The sex of the specimens was determined by observing the external morphology of the abdomen and measuring the carapace width $\left(W_{c}\right)$. The measurements were performed using a caliper with an accuracy of $0.01 \mathrm{~mm}$. The specimens captured by the researchers were returned to the mangrove after collecting biometric data. The data were organized and divided into categories of $0.5 \mathrm{~cm}$ of carapace width.

Selectivity was calculated by a procedure similar to that used for a trawl, treating the individuals collected by the fishermen in the delimited area as those harvested by the trawl's codend, and the remaining individuals in the area removed by the researchers as those harvested by the trawl's covered codend (Kimura, 1978; Hoydal et al., 1982).

The total number of individuals in the area $\left(n_{i}\right)$ and the total number of captured individuals $\left(y_{i}\right)$ was known for each $i$-th category of carapace width, with binomial probability distribution $\operatorname{Bin}\left(n_{i}, p_{i}\right)$, where $n_{i}$ is the total number of individuals in the area and $p_{i}$ is the probability of an individual of category $i$ being captured on the premise that larger individuals are more likely to be captured.

The selectivity described by the parameters $p_{i l}, p_{i 2}$, $\ldots p_{i L}$ for all carapace width classes was summarized by parametric function $f(W c ; \theta)$ using the inverse logistic curve which is the most commonly used among other sigmoid shapes (Holst, 2007) Equation 1:

$$
f\left(W c ; \beta_{0}, \beta_{1}\right)=\exp \left(\beta_{0}+\beta_{1}\right) /\left[1+\exp \left(\beta_{0}+\beta_{1}\right)\right]
$$

The logit of $p_{i}$ function was used in the formulation of the logistic model for the probabilities of $p_{i}$ Equation 2:

$$
\log \left(p_{i} /\left(1-p_{i}\right)\right)=\beta_{0}+\beta_{1}\left(x_{i}-\bar{x}\right)
$$

The inclusion of the mean carapace width $(\bar{x})$ aimed to centralize the logistic regression and facilitate the interpretation of $\beta_{0}$, which is the logit transformation of the probability of capturing an individual with carapace width equal to the mean $(\bar{x})$, and of $\beta_{l}$, which is the mean increase in the logit of $p_{i}$ for each centimeter added to the carapace width. 
The solution to the calculation of $x$ that corresponds to $\mathrm{Wc}_{25}, \mathrm{Wc}_{50}$, and $\mathrm{Wc}_{75}$ was obtained by replacing $p_{i}$ by 0.25 $(25 \%), 0.50(50 \%)$, and $0.75(75 \%)$ in the above equation, respectively. $\mathrm{Wc}_{50}$ is the selectivity size and $\mathrm{Wc}_{25-75}$ is the selectivity interval $I_{\text {s. }}$.

The relationship between the model and the data was formalized by the binomial likelihood function Equation 3:

$$
L\left(\beta_{0}, \beta_{1}\right) \propto \prod_{i=1}^{n} p_{i}^{y_{i}}\left(1-p_{i}\right)^{\left(n_{i}-y_{i}\right)}
$$

Each $p_{i}$ value is a function of the parameters $\beta_{0}$ and $\beta_{1}$ and of the carapace width $x_{i}$ Equation 4:

$p_{i}=\exp \left[\beta_{0}+\beta_{1}\left(x_{i}-\bar{x}\right)\right] /\left(1+\exp \left[\beta_{0}+\beta_{1}\left(x_{i}-\bar{x}\right)\right]\right)$

The estimated values of $\mathrm{Wc}_{25}, \mathrm{Wc}_{50}$, and $\mathrm{Wc}_{75}$ were obtained by replacing the parameters $\beta_{0}$ and $\beta_{1}$ by the corresponding maximum likelihood estimations.

The calculation of the accuracy for $\mathrm{Wc}_{25}, \mathrm{Wc}_{50}$, and $\mathrm{Wc}_{75}$ was performed by exploring the uncertainties on the estimations of $\beta_{0}$ and $\beta_{1}$ on which $\mathrm{Wc}_{25}, \mathrm{Wc}_{50}$, and $\mathrm{Wc}_{75}$ depend, via the exploration of the posterior distributions of $\beta_{0}$ and $\beta_{l}$. Because there are two parameters, this is a distribution of the joint probability of $\beta_{0}$ and $\beta_{l}$. The Bayesian inference consisted of obtaining the posterior distribution by applying the Markov chain Monte Carlo (MCMC) method in the software R (R Core Team, 2013) using the OpenBUGS, BRugs (Thomas et al., 2006), and R2WinBUGS (Sturtz et al., 2005) packages in the Windows system, with a chain of 50,000 cycles, and a burn-in period of the first 41,000 cycles. Of the remaining 9,000 cycles, only 3,000 values with an interval of three steps between each other were retained. To determine whether a stationary distribution was achieved in the MCMC procedure, graphs were generated and diagnostic tests were performed using the CODA package (Plummer et al., 2006). Normal priori distributions were used, with means $(0)$ and weakly informative with accuracy values $(0.001)$.

\section{Results and Discussion}

The number of total and captured male and female crabs in the areas delimited by the 87 squares during the 29 fishing trips that occurred in Brazil's north coast between 1998 and 2007 are shown in Figure 1.
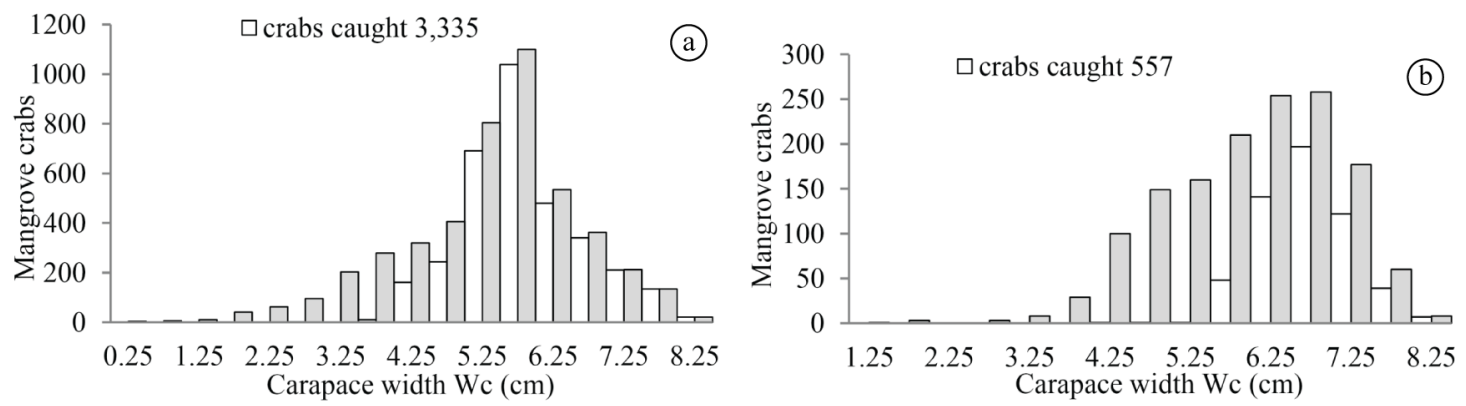

Figure 1. Number of total and captured male (a) and female (b) crabs (b), by category of carapace width.
Based on the proposal of the Cancun Conference on Responsible Fishing (Declaration of Cancun, 1992), fishing selectivity is defined as the ability to select and harvest by species, size, or sex (or by the combination of these factors) during search and harvest operations, to minimize wasteful capture of target-species and minimize bycatch of nontarget species.

The fishermen only excluded ovigerous females (those carrying eggs attached to the body), molting specimens, and small-sized individuals. This suggests that crab fishermen are somehow careful with regard to the preservation of this species' stock. Figure 2 shows that the proportion of captured individuals positively correlates with carapace width.

The results of the (general linear model) glm function provided estimations of maximum likelihood of $\beta_{0}$ and $\beta_{1}$ for males and females. Selectivity parameters were obtained based on these results (Table 1).

The selectivity curve of a specific fishery for a given species is characterized by the selectivity parameters. The estimated parameters were $\mathrm{Wc}_{25}, \mathrm{Wc}_{50}$, and $\mathrm{Wc}_{75}$, which represent the carapace widths corresponding to the retention probabilities of $25 \%, 50 \%$, and $75 \%$, respectively, of the individuals that enter the fishermen's visual field $\left(\mathrm{Wc}_{50}\right.$ is a basic measure of the selectivity of a fishery because it provides practical information on the selectable average size in the fishery), and the selectivity interval $\mathrm{I}_{\mathrm{S}}$ corresponded to the difference between $\mathrm{Wc}_{25}$ and $\mathrm{Wc}_{75}$, which represents the slope of the selectivity curve (Table 2).

In both the classical and Bayesian inference, the likelihood function is extremely important to provide sample information. The principle of this function sustains that all the information provided by the sample or by the experiment is contained in the likelihood function (Paulino et al., 2003), i.e., this principle postulates that the inference of a quantity of interest $(\theta)$ only depends on what was observed and not on what could have occurred but did not in fact occur (Ehlers, 2007). The posteriori results of the Bayesian analysis of selectivity are shown in Tables 3 and 4 and in Figures 3 and 4 . The calculation of percentiles $2.5 \%$ and $97.5 \%$ (Table 4 ) is used to quantify the range containing $95 \%$ of the most probable values as $\mathrm{Wc}_{50}(5.47$ to $5.57 \mathrm{~cm})$ for males and $(6.34$ to $6.50 \mathrm{~cm})$ for female crabs. 


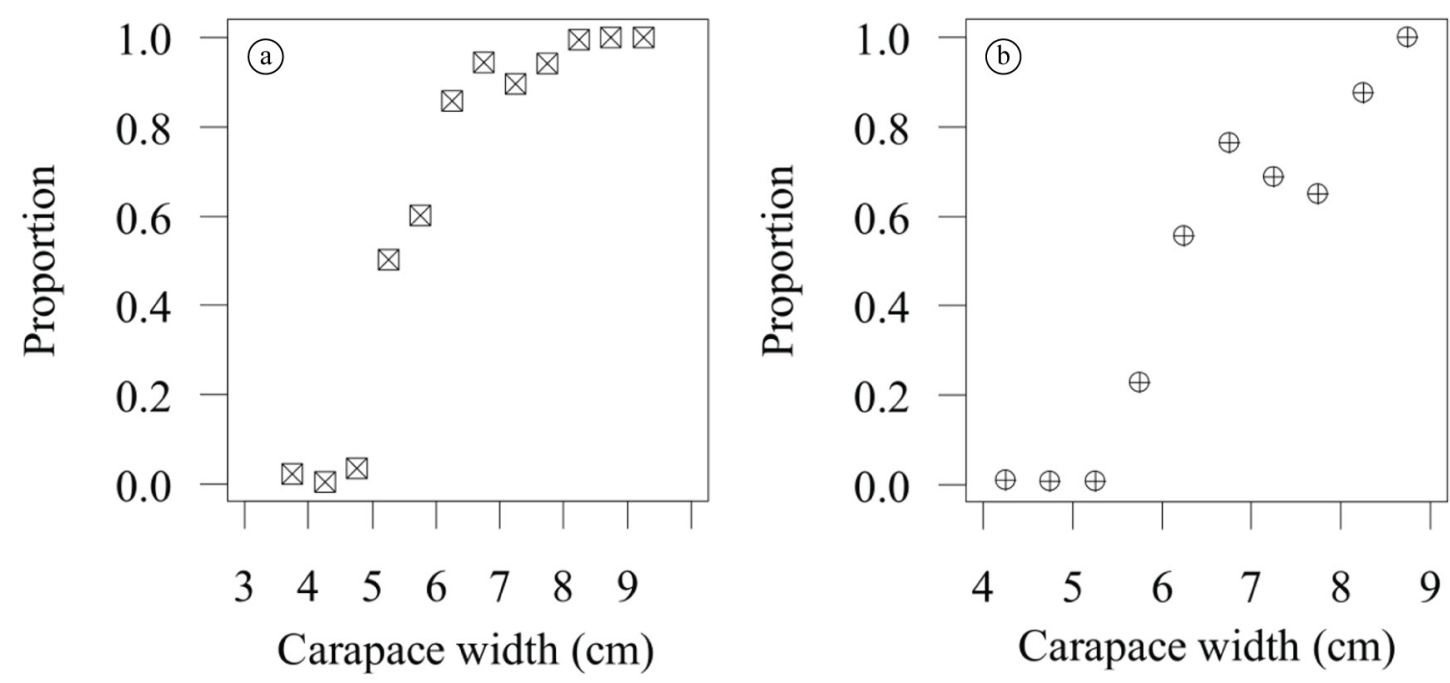

Figure 2. Relation between carapace width and proportion of captured individuals, (a) males and (b) females.

Table 1. Values of estimations of maximum likelihood of $\beta_{0}$ and $\beta$, for male and female crabs.

\begin{tabular}{|c|c|c|c|c|}
\hline Coefficients (male) & Estimate & Stand. Error & $\mathrm{Z}$ value & $\operatorname{Pr}(>|z|)$ \\
\hline$\beta_{0}$ & 1.93244 & 0.05892 & 32.80 & $<2 \mathrm{e}-16$ \\
\hline$\beta_{1}$ & 1.97854 & 0.06149 & 32.18 & $<2 \mathrm{e}-16$ \\
\hline Null deviance & 2308.51 & $\begin{array}{l}11 \text { degrees of } \\
\text { freedom }\end{array}$ & AIC & 267.98 \\
\hline Residual deviance & 217.76 & $\begin{array}{l}10 \text { degrees of } \\
\text { freedom }\end{array}$ & & \\
\hline $\mathrm{n}^{\mathrm{o}} \mathrm{F}$ iterations & 5 & & & \\
\hline Coefficients (female) & Estimate & Stand. Error & $\mathrm{Z}$ value & $\operatorname{Pr}(>|z|)$ \\
\hline$\beta_{0}$ & 0.14000 & 0.07017 & 1.995 & 0.046 \\
\hline$\beta_{1}$ & 1.75012 & 0.09815 & 17.830 & $<2 \mathrm{e}-16$ \\
\hline Null deviance & 663.71 & $\begin{array}{l}7 \text { degrees of } \\
\text { freedom }\end{array}$ & AIC & 162.31 \\
\hline Residual deviance & 123.41 & $\begin{array}{l}6 \text { degrees of } \\
\text { freedom }\end{array}$ & & \\
\hline $\mathrm{n}^{\mathrm{o}} \mathrm{F}$ iterations & 5 & & & \\
\hline
\end{tabular}

Table 2. Values of the parameters of the selectivity logistic curves, selectivity size, and selectivity interval for male and female crabs.

\begin{tabular}{ccc}
\hline & Male & Female \\
\hline $\mathrm{Wc}_{50}(\mathrm{~cm})$ & 5.52 & 6.42 \\
$\mathrm{Wc}_{25}(\mathrm{~cm})$ & 5.28 & 6.15 \\
$\mathrm{Wc}_{75}(\mathrm{~cm})$ & 5.76 & 6.69 \\
$\mathrm{I}_{\mathrm{s}}(\mathrm{cm})=\mathrm{Wc}_{25}-\mathrm{Wc}_{75}$ & 0.48 & 0.54 \\
\hline
\end{tabular}

The selectivity curves for male and female mangrove crabs are shown in Figure 5. Four studies have been conducted on the size of the first maturation in the fishing area (Table 5). In the three most recent studies, the carapace width values for females and males at the time of first maturity were lower than $\mathrm{Wc}_{50}$ capture. Although it is not possible to test the significance of the differences, the physiological and morphological maturity values for males (the main target in fisheries) are very similar.

In Brazil, the capture of mangrove crabs is allowed throughout the year, except during the reproductive periods known as "stepped", which are established every year by the Ministry of Fisheries and Aquaculture (MPA) and the Ministry of Environment (MMA). It is prohibited to capture individuals of both sexes with a carapace width of $<6.0 \mathrm{~cm}$, and there is an annual period in which the harvest of female crabs is prohibited in the States of North and Northeast.

The pressure exerted by fishermen on the Ucides cordatus population is mainly because of the fact that they captured individuals with a carapace width of $<6.0 \mathrm{~cm}$ (transgressing the environmental law). On the other hand, the first sexual maturation size is smaller than the capture 
Table 3. Posteriori values of $\beta$ and $\beta$, for male and female crabs.

\begin{tabular}{cccccccc}
\hline Males & Mean & sd & $\mathbf{2 . 5 \%}$ & $\mathbf{2 5 \%}$ & $\mathbf{5 0 \%}$ & $\mathbf{7 5 \%}$ & $\mathbf{9 7 . 5 \%}$ \\
\hline$\beta_{0}$ & 1.93 & 0.06 & 1.82 & 1.89 & 1.93 & 1.97 & 2.05 \\
$\beta_{1}$ & 1.98 & 0.06 & 1.86 & 1.94 & 1.98 & 2.02 & 2.10 \\
Deviance & 265.99 & 2.08 & 264.03 & 264.54 & 265.34 & 266.79 & 271.63 \\
$\mathrm{pD}=2.0$ & $\mathrm{DIC}=268.0$ & & & & & \\
\hline Females & Mean & sd & $\mathbf{2 . 5 \%}$ & $\mathbf{2 5 \%}$ & $\mathbf{5 0 \%}$ & $\mathbf{7 5 \%}$ & $\mathbf{9 7 . 5 \%}$ \\
\hline$\beta_{0}$ & 0.14 & 0.07 & 0.002 & 0.09 & 0.14 & 0.19 & 0.28 \\
$\beta_{1}$ & 1.75 & 0.10 & 1.57 & 1.68 & 1.75 & 1.82 & 1.97 \\
Deviance & 160.36 & 2.13 & 158.36 & 158.88 & 159.68 & 161.14 & 166.05 \\
$\mathrm{pD}=2.0$ & $\mathrm{DIC}=162.3$ & & & & &
\end{tabular}

Table 4. Posteriori values of the parameters of the selectivity logistic curves, size selectivity, and percentiles of Wc for male and female crabs.

\begin{tabular}{cccccccc}
\hline \multirow{4}{*}{ Males } & & Mean & $\mathbf{2 . 5 \%}$ & $\mathbf{2 5 \%}$ & $\mathbf{5 0 \%}$ & $\mathbf{7 5 \%}$ & $\mathbf{9 7 . 5 \%}$ \\
\hline \multirow{3}{*}{ Females } & $\mathrm{Wc}_{25}$ & 5.28 & 5.22 & 5.26 & 5.28 & 5.30 & 5.34 \\
& $\mathrm{Wc}_{50}$ & 5.52 & 5.47 & 5.51 & 5.52 & 5.54 & 5.57 \\
& $\mathrm{Wc}_{75}$ & 5.76 & 5.71 & 5.75 & 5.76 & 5.78 & 5.81 \\
\hline & $\mathrm{Wc}_{25}$ & 6.15 & 6.07 & 6.12 & 6.15 & 6.17 & 6.23 \\
& $\mathrm{Wc}_{50}$ & 6.42 & 6.34 & 6.39 & 6.42 & 6.45 & 6.50 \\
& $\mathrm{Wc}_{75}$ & 6.69 & 6.61 & 6.66 & 6.69 & 6.72 & 6.78 \\
\hline
\end{tabular}
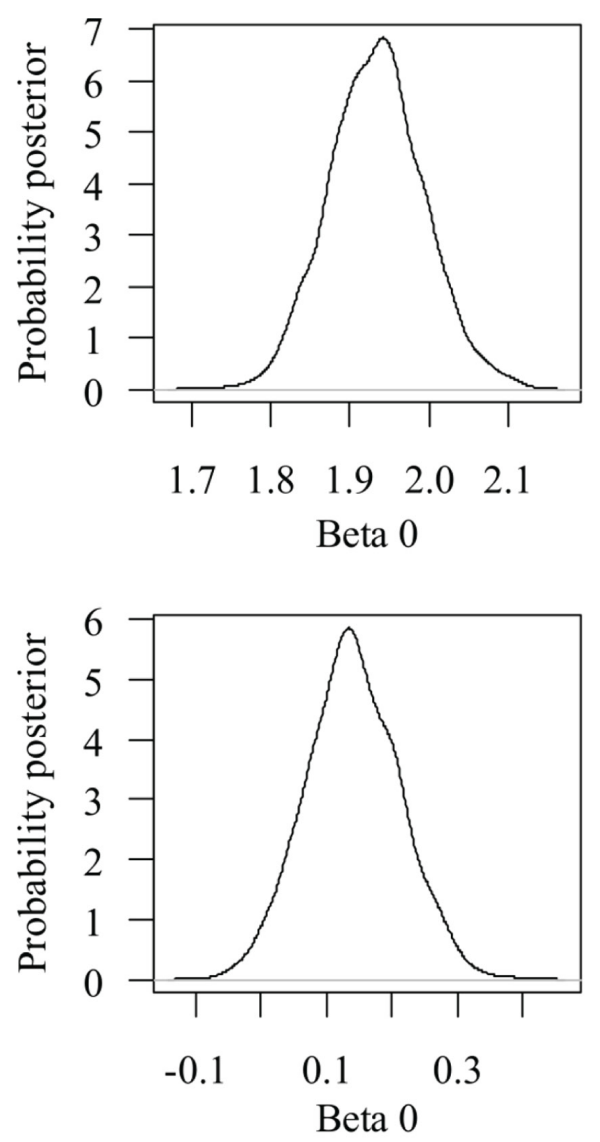

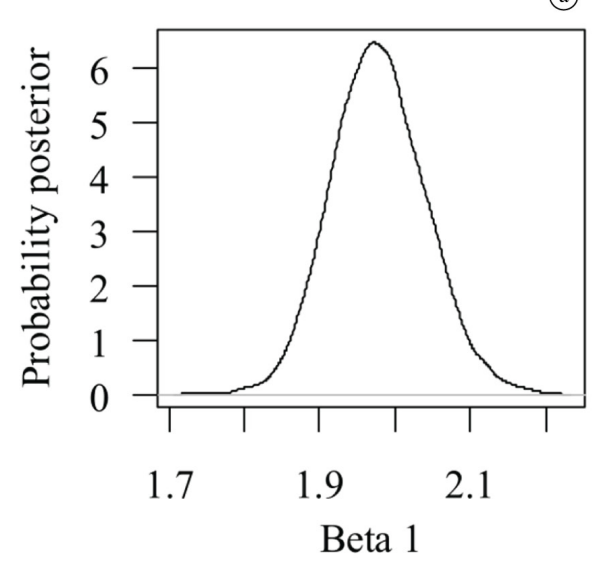

(b)

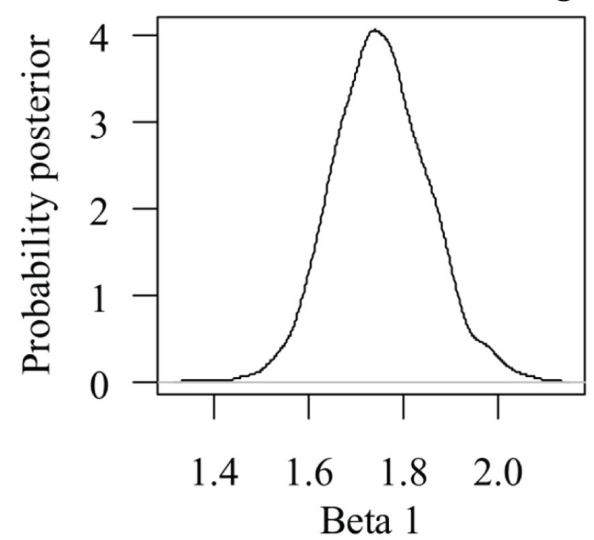

Figure 3. Posteriori densities of $\beta_{0}$ and $\beta_{1}$ for male (a) and female (b) crabs. 

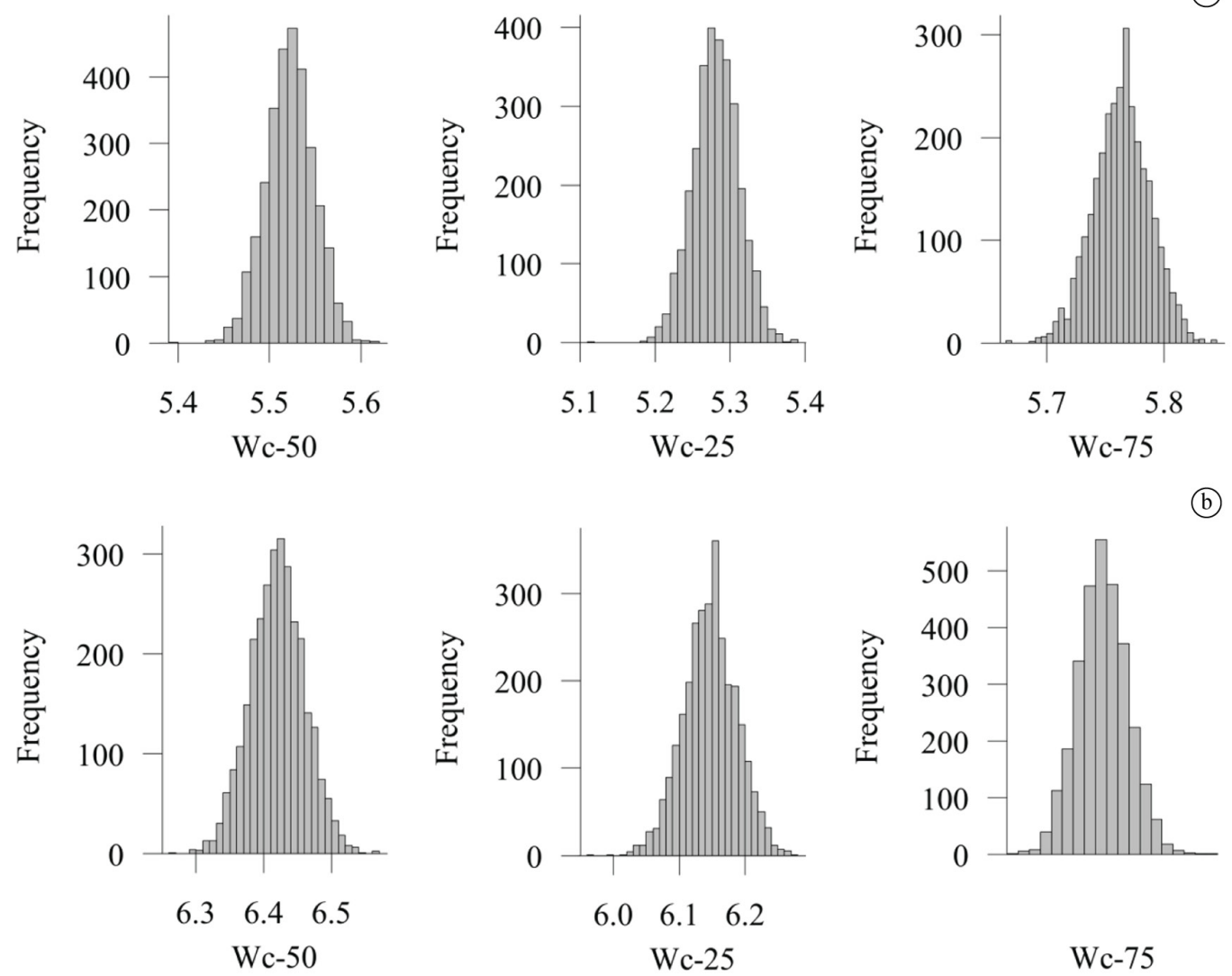

6.06 .16 .2

Wc-25

Wc-75

Figure 4. Histograms of parameters $\mathrm{Wc}_{50}, \mathrm{Wc}_{25}$, and $\mathrm{Wc}_{75}$ posteriori of logistic selectivity curves for male (a) and female (b) crabs.
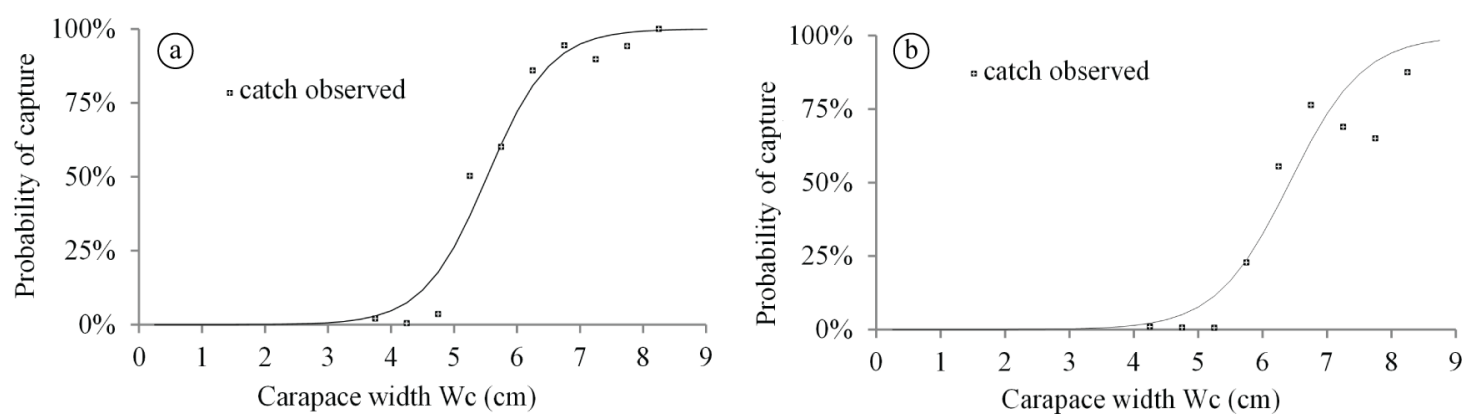

Figure 5. Catch observed and fishing selectivity curve of mangrove male (a) and female (b) crabs.

Table 5. Size of first sexual maturation of $U$. cordatus in mangrove ecosystems in the north coast of Brazil (carapace width in $\mathrm{mm}$ ).

\begin{tabular}{|c|c|c|c|c|}
\hline Female & Male & Analysis type & Place & Author \\
\hline 3.74 & & Macroscopic physiological & Muriá River-PA & Silva et al. (2009) \\
\hline & 3.99 & Morphological Wc x Lplc & \multirow{4}{*}{ Igaraçú River-PI } & \multirow{4}{*}{ Linhares (2010) } \\
\hline 4.60 & & Morphological Wc x Wa & & \\
\hline & 3.64 & Morphological Wc x Lg & & \\
\hline 3.27 & 3.51 & Microscopic physiological & & \\
\hline 4.02 & 3.51 & Microscopic physiological & Caeté River-PA & Vale (2003) \\
\hline 5.76 & 6.08 & Macroscopic physiological & Parnaíba River-MA/PI & Ivo et al. (1999) \\
\hline
\end{tabular}


$\mathrm{Wc}_{50}$ obtained both for males and females, which reduces the risk for overfishing.

However, Domingues (2008) reported that sexual selectivity is a common practice in mangrove crab exploitation. Female crabs are not captured and only the larger males are harvested. Although selectivity is influenced by the market, in the case of the production system for marketing live crabs, the price is proportional to the size of the crab and the trade of female crabs is also restricted.

Castro et al. (2008) observed that the proportion of meat yield was $26.0 \%$ for males and $19.3 \%$ for females, which is relative to the weight of the whole animal, and that the harvest practiced by fishermen excluded ovigerous females and specimens with a carapace width of $<6.0 \mathrm{~cm}$, which may indicate that the community is aware of the need to preserve the species.

Moreover, the crab collectors report cultural reasons for not capturing the female "countess"; they reported that when they were starting this activity, the most experienced professionals, usually their grandfathers, parents, uncles, or neighbors, explained that they should preferably catch larger crabs, and that females should be left in the mangrove because they were responsible for stock replenishment (Leite, 2003; Domingues, 2008).

Sexual and size selectivity in crab fishing include a high sustainability potential. It is noteworthy that although this fishing has been practiced for a long time (more than 50 years) and the growth of $U$. cordatus is slow, large males are still observed in abundance. This indicates that the system has a high cushioning capacity, possibly because of the numerous sanctuaries, such as areas with dense roots that prevent the capture of crabs. Therefore, exploitation of the whole area is avoided, and the mosaic of sanctuaries may act as a source of replenishment of fishing sites (Diele, 2000).

Selection is a process by which recruited crabs progressively enter the exploitation phase. The term "retention" would be more appropriate to distinguish this selection process from the selection of a target species or a target age group, through the preferential application of the fishing effort. The rate of retention of a crab with a given carapace width is the probability of being retained by the fisherman once found and captured.

Considering the form of capture and the way the fisherman handles the captured animal, this should be the most selective fishing of all. Using a template, the fisherman simply needs to compare the width of the captured animal to the required size. However, this estimation of the carapace width is visually performed and some captured animals are smaller than the required size.

\section{Conclusion}

Considering the low meat yield and the low receptivity of intermediaries and consumers who do not buy females or individuals with a carapace width of $<5.5 \mathrm{~cm}$, we conclude that the capture of smaller and female crabs incidentally occurs, and that the larger individuals that are more valued in the market are the target.

Considering that the size of first sexual maturation of male crabs is the main target of fisheries, which is estimated by the mean of the three most recent studies published for the north coast, is $4 \mathrm{~cm}$ of carapace width, we conclude that the most mature individuals do not suffer from fishing pressure and this ensures their sustainability.

The study has demonstrated that the selectivity method applied was realist and also may be used for other exploited fishery resource for commercial fishing.

\section{References}

BERGER, J.O., 1993. Statistical decision theory and bayesian analysis. 2nd ed. New York: Springer.

BRASIL. Ministério da Pesca e Aquicultura-MPA, 2011 [viewed 23 April 2014]. Boletim estatístico da pesca e aquicultura: Brasil 2008-2009 [online]. Brasília: Ministério da Pesca e Aquicultura. Available from: http://www.mpa.gov.br/images/Docs/Publicidade/ anu $\%$ C3\%A1rio $\% 20$ da $\% 20$ pesca $\% 20$ completo2.pdf

BRASIL. Ministério da Pesca e Aquicultura-MPA, 2013 [viewed 23 April 2014]. Boletim estatístico da pesca e aquicultura: Brasil 2011 [online]. Brasília: Ministério da Pesca e Aquicultura. Available from: http://www.mpa.gov.br/images/Docs/Informacoes_e_Estatisticas/ Boletim\%20MPA\%202011FINAL3.pdf

CASTRO, A.C.L., CORREIA, M.M.F., NASCIMENTO, A.R., PIEDADE-JÚNIOR, R.N., GAMA, L.R.M., SOUSA, M.M., SENA, A. C.S. and SOUSA, R.C.C., 2008. Biological aspects of the mangrove crab (Ucides cordatus, 1. 1763) (Decapoda, Brachyura) in mangals of São Luis island in the northeastern coast of Maranhão state, Brazil. Amazônia. Ciência \& Desenvolvimento, vol. 3 , no. 6 , pp. 17-36.

DECLARATION OF CANCUN, 1992 [viewed 23 April 2014]. Declaration of the International Conference on Responsible Fishing. In: Proceedings of the International Conference on Responsible Fishing [online], 6-8 May 1992, Cancun, Mexico. Rome: Food and Agriculture Organization of the United Nations, 4 p. Available from: http://legal.icsf.net/icsflegal/uploads/pdf/ instruments/res0201.pdf

DIELE, K., 2000. Life history and population structure of the exploited mangrove crab U. cordatus (L.) (Decapoda: Brachyura) in the Caeté estuary, North Brazil. Bremen: Universität Bremen. $\mathrm{PhD}$ Thesis der Naturwissenschaften.

DOMINGUES, D., 2008. Análise do conhecimento ecológico local e do sistema produtivo como subsídio para gerar instrumentos de gestão da atividade de exploração do caranguejo-uçá (Ucides cordatus Linneaus, 1763) nos manguezais da Reserva Extrativista Marinha Caeté-Taperaçu, Bragança-PA. Bragança: Universidade Federal do Pará. Dissertação de Mestrado em Biologia Ambiental.

EHLERS, R.S., 2007 [viewed 23 April 2014]. Introdução à inferência bayesiana [online]. Available from: http://www.icmc. usp.br/pessoas/ehlers/bayes/bayes.pdf

HOLST, R., 2007. Summary of statistical methods for towed gear selectivity analysis. FAO Fisheries Report: Workshop on standardization of selectivity methods applied to trawling in the Mediterranean Sea, 9-11 February 2005, Sète, France. Rome: Food and Agriculture Organization of the United Nations, pp. 35-37. 
HOYDAL, K., RØRVIK, C.J. and SPARRE, P., 1982. Estimation of effective mesh sizes and their utilization in assessment. Dana, vol. 2 , no. 1 , pp. 69-95.

INSTITUTO BRASILEIRO DO MEIO AMBIENTE E DOS RECURSOS NATURAIS RENOVÁVEIS - IBAMA, 2007. Estatística da pesca 2007: Brasil Grandes Regiões e Unidades da Federação. Brasília: IBAMA.

IVO, C.T.C., DIAS, A.F. and MOTA, R.I., 1999. Estudo sobre a biologia do caranguejo-uçá, Ucides cordatus cordatus, (Linnaeus, 1763) capturado no delta do rio Parnaíba, estado do Piauí. Boletim Técnico-Cientifico do CEPENE, vol. 7, no. 1, pp. 53-84.

KIMURA, D.K., 1978. Logistic model for estimating selection ogives from catches of codends whose ogives overlap. Journal du Conseil, vol. 38, no. 1, pp. 116-119. http://dx.doi.org/10.1093/ icesjms/38.1.116.

KJERFVE, B. and LACERDA, L.D., 1993. Mangroves of Brazil. In: L.D. LACERDA, ed. Conservation and sustainable utilization of mangrove forests in Latin America and Africa regions. Part $I$ - Latin America. Okinawa: International Society for Mangrove Ecosystems, pp. 245-272.

$\mathrm{KOCH}, \mathrm{V}$. and WOLFF, M., 2002. Energy budget and ecological role of mangrove epibenthos in the Caeté estuary, North Brazil. Marine Ecology Progress Series, vol. 228, no. 1, pp. 119-130. http://dx.doi.org/10.3354/meps228119.

LEITE, J.C.B., 2003. A estrutura populacional e o potencial extrativo do caranguejo-uçá (Ucides cordatus Linnaeus, 1763) em três áreas de manguezal de São Caetano de Odivelas-PA. Belém: Universidade Federal do Pará. Dissertação de Licenciatura em Ciências Biológicas.

LINHARES, J.C.S., 2010. Estratégias reprodutivas do caranguejo Ucides cordatus (Crustacea; Brachyura; Ucididae). Fortaleza: Universidade Federal do Ceará. Dissertação de Mestrado em Ecologia e Recursos Naturais.

MAIA, L.P., HISLEI, L., MONTEIRO, U., SOUZA, G.M. and LACERDA, L.D., 2006. Changes in mangrove extension along the Northeastern Brazilian coast (1978-2003). ISME/GLOMIS Electronic Journal, vol. 5, no. 1, pp. 1-5.

MANESCHY, M.C., 1993. Pescadores nos manguezais: estratégias técnicas e relações sociais de produção na captura de caranguejo. In: L.G. FURTADO, W. LEITÃO and A.F. MELLO, eds. Povos das águas: realidade e perspectiva na Amazônia. Belém: Museu Paraense Emilio Goeldi, pp. 19-62.
NORDHAUS, I., WOLFF, M. and DIELE, K., 2006. Litter processing and population food intake of the mangrove crab Ucides cordatus in a high intertidal forest in Northern Brazil. Estuarine, Coastal and Shelf Science, vol. 67, no. 1-2, pp. 239-250. http:// dx.doi.org/10.1016/j.ecss.2005.11.022.

PAULINO, C.D., TURKMAN, M.A.A. and MURTEIRA, B., 2003. Estatística Bayesiana. Lisboa: Fundação Calouste Gulbenkiman.

PLUMMER, M., BEST, N., COWLES, K. and VINES, K., 2006. CODA: Convergence Diagnosis and Output Analysis for MCMC. $R$ News, vol. 6, no. 1, pp. 7-11.

R CORE TEAM, 2013 [viewed 23 April 2014]. R: A language and environment for statistical computing [online]. Vienna: $\mathrm{R}$ Foundation for Statistical Computing. Available from: http://www. 1sw.uni-heidelberg.de/users/christlieb/teaching/UKStaSS10/Rrefman.pdf

SILVA, K.C.A., FERREIRA, I.L.S., IVO, C.T.C., ARAÚJO, M.V.L.F., KLAUTAU AG, C.M. and CINTRA, I.H.A., 2009. Sobre a reprodução do caranguejo-uçá Ucides cordatus na reserva extrativista Marinha Mãe Grande de Curuçá, Pará, Brasil. Boletim Técnico-Cientifico do CEPNOR, vol. 9, no. 1, pp. 9-23. http:// dx.doi.org/10.17080/1676-5664/btcc.v9n1p9-23.

SOUZA-FILHO, P.W.M., 2005. Costa de manguezais de macromaré da Amazônia: cenários morfológicos, mapeamento e quantificação de áreas usando dados de sensores remotos. Revista Brasileira de Geofisica, vol. 23, no. 4, pp. 427-435. http://dx.doi.org/10.1590/ S0102-261X2005000400006.

SPARRE, P. and VENEMA, S.C., 1998. Introduction to tropical fish stock assessment. Rome: Food and Agriculture Organization of the United Nations. FAO Fisheries Technical Paper, vol. 306, no. 1.

STURTZ, S., LIGGES, U. and GELMAN, A., 2005. R2WinBUGS: a package for running WinBUGS from R. Journal of Statistical Software I, vol. 12, no. 3, pp. 1-16.

THOMAS, A., O'HARA, B., LIGGES, U. and STURTZ, S., 2006. Making BUGS open. $R$ News, vol. 6, no. 1, pp. 12-17.

VALE, P.A.A., 2003. Biologia reprodutiva do caranguejo Ucides cordatus cordatus (Linnaeus, 1763), no manguezal do estuário do rio Caeté, Bragança, Pará, Brasil. Bragança: Universidade Federal do Pará. Dissertação de Mestrado em Biologia Ambiental.

WALTERS, C.J. and MARTELL, S.J.D., 2004. Fisheries Ecology and Management. New Jersey: Princeton University Press. 